\title{
The Abrasion Behaviour of X40CrMoV5-1 Steel Under Various Surface Treatments
}

\author{
László TÓTH, ${ }^{1}$ Tünde KOVÁCS, ${ }^{2}$ Zoltán NYIKES, ${ }^{3}$ Mhatre UMESH ${ }^{4}$ \\ ${ }^{1}$ Óbudai University, Bánki Donát Faculty of Mechanical and Safety Engineering, Department of Materials \\ Technology, Budapest, Hungary, toth.laszlo@bgk.uni-obuda.hu \\ ${ }^{2}$ Óbudai University, Bánki Donát Faculty of Mechanical and Safety Engineering, Department of Materials \\ Technology, Budapest, Hungary, kovacs.tunde@ bgk.uni-buda.hu \\ ${ }^{3}$ Óbudai University, Bánki Donát Faculty of Mechanical and Safety Engineering, Department of Materials \\ Technology, Budapest, Hungary, zoltan.nyikes@bgk.uni-obuda.hu \\ ${ }^{4}$ Surface Modification Technologies Pvt. Ltd. Research and Developement La, India, Sativali Road Vasai \\ Road- (East), Dist. Palghar, Maharashtra-401208, umhatre@hotmail.com
}

\begin{abstract}
For evolving a surface layer on the X40CrMoV5-1 steel, a plasma-nitridation and PVD coating process was applied. In our experiments, the samples were heat-treated (high-temperature hardening, annealed three times) and surface treatments (plasma-nitridation, PVD coating by TiAlN, duplex surface treating by plasma nitridation and after that, PVD coating TiAlN). After the heat treatments, we performed hardness tests and surface abrasion wear tests. The abrasion wear resistance of the specimens was studied in order to understand the heat treatment effects on abrasion behaviour. It was observed that the heat treatment and surface treatment process greatly influence the tool steel surface hardness and abrasion resistance behaviour.

By plasma-nitridation the surface hardness doubled compared to the quenched surface hardness while the PVD coated TiAlN surface layer hardness is more than five times that of the hardened one. There was no relevant difference between the PVD coated (TiAlN) surface hardness and the duplex surface-treated hardness. On the basis of the results of the comparative abrasive wear tests, it can be concluded that the duplex surface treatment resulted in the greatest wear resistance..
\end{abstract}

Keywords: tool steel, secondary hardening, austenitization, PVD coating, hardness, plasma nitriding.

\section{Introduction}

It is characteristic of hot-forming tool steels that they often have to meet opposing requirements at the same time, i.e. they have to function under the combined effect of different stresses. It follows that the main properties of the hot forming tool steels are hot strength, hardness, abrasion resistance, toughness, annealing resistance, thermal fatigue resistance, hot workability and machinability. These properties can be achieved partly by alloying with different chemical elements and partly by applied special heat treatment technologies. Depending on their use, there are cases where the toughness and abrasion resistance of the material are required at the same time. In such cases, surface treatments are used. The abrasion resistance, high strength and toughness can all be achieved at the same time by applying a thin wear-resistant layer on the surface of the material. This is possible in several ways.

The X40CrMoV5-1 steel belongs to the family of hot working tool steels which is known among tool makers as EN 1.2344 The material has a very good heat resistance and hot wear resistance [1, 2]. These steels retain their properties even when working at temperatures of up to $200{ }^{\circ} \mathrm{C}$, due to the optimal heat treatment technology and the chemical composition of the material. An increase in surface abrasion resistance is achieved by creating a thin abrasion-resistant layer [3, 4]. This can be achieved by nitriding or/and coating on hot forming tool steels. 
Plasma nitriding technology was introduced in 1920, but in industrial applications has been only used for the past 30 years. The plasma nitriding technology is a thermochemical surface treatment process which is carried out at a temperature of $350-600{ }^{\circ} \mathrm{C}$. In front of the furnace wall serving as an anode, positive ions collide at high impact velocities with workpieces connected to the cathode. This ionic shower first produces a very intensive surface cleaning and then heats and nitrides the workpiece surface [5].

Plasma nitridation can be performed in both DC and pulsed plasma. Plasma nitridation takes place in a vacuum furnace (200 to $500 \mathrm{~Pa}$ pressure), in an ionized gas atmosphere (ammonia, nitrogen, methane or hydrogen), but gas mixtures are also used to form more abrasion resistant surface layers.

The quality of the heat treatment is determined by the composition of the gas, the pressure, the temperature and the duration of the operation. The upper part of the nitride layer (up to $30 \mu \mathrm{m}$ depending on the material) is hard and chemically stable, and below it is the diffusion zone with max. $1 \mathrm{~mm}$ thickness.

In the case of hot-forming tool steel, a surface hardness of 850-950 HV can be achieved up to a depth of $0.4 \mathrm{~mm}$ by plasma nitriding. The process improves the abrasion and sliding properties of the materials and creates a corrosion-resistant layer on the material surface. The dimension distortion is very small. Plasma nitriding is usually used as the final process in finished parts because after this treatment no machining is required.

The dimensions of nitrided workpieces increase by $\sim 1 \%$ of the bark thickness, which is an insignificant change. This procedure allows precise control of the process, fine-tuning of the microstructure of the nitride layer, and thus achieving the desired properties. PVD surface treatment is a physical vapour deposition in which the coating material is applied to the surface of the coating component in atomic, chemical compounds or ionic form. PVD processes take place at relatively low temperatures, which means that the process does not modify the tissue structure of the sublayer and there is no allotropic transformation so that the surface-treated tool does not suffer any dimensional changes.

The PVD coating provides good sliding properties, high abrasion resistance and high hardness on the tool surface. The main purpose of the surface treatments was to increase the wear resistance of the tool. The abrasive wear is a complex system of microscopic interactions that occur be- tween sliding surfaces. These interactions depend on the contact surfaces of the materials, on their physical, chemical, mechanical properties, of the geometry, and external conditions that affect the wear (e.g., temperature) [6-7].

Wear processes can only be investigated in a well-defined wear system, for comparison, measured results that have been determined in a similar tribological system and where only the investigated parameter changes, other parameters are minimized [8-9]. Tool wear resistance is not easy to predict. Hardness measurement is used in many places in the industry for this purpose, as there is some correlation between abrasion resistance and hardness. Similarly, comparative experimental methods are widespread, e.g. ball / flat abrasion test [10-12]. During our measurements, we examined the wear resistance of the specimens with different heat treatment and surface treatment by a comparative method and also compared their hardness values.

\section{The experimental materials and technologies}

The chemical composition of the tested $\mathrm{X} 40 \mathrm{CrMoV5}-1$ steel specimens is shown in Table 1.

Table 1. Chemical composition (\%)

\begin{tabular}{|c|c|c|c|c|c|}
\hline $\mathbf{C}$ & $\mathbf{S i}$ & $\mathbf{M n}$ & $\mathbf{C r}$ & Mo & V \\
\hline 0.40 & 1.10 & 0.45 & 5.25 & 1.41 & 1.2 \\
\hline
\end{tabular}

The austenitization of the samples was performed in a VFC type $300 \times 370 \times 200 \mathrm{~mm}$ Ipsen vacuum furnace with two-stage heating $\left(650^{\circ} \mathrm{C}\right.$ and $850{ }^{\circ} \mathrm{C}$, respectively) at $1050{ }^{\circ} \mathrm{C}$. The cooling was performed with 6 bar nitrogen gas. The quenching was followed by triple high-temperature tempering (Figure 1.).

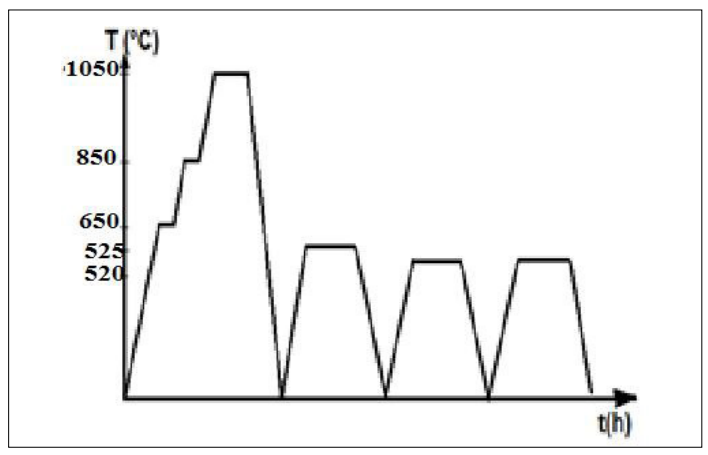

Figure 1. Az X40CrMoV5-1 steel heat treatments diagram. 
Tempering was performed in a $300 \times 370 \times 350 \mathrm{~mm}$ Muehl furnace under argon gas each with two hours heating times.

After each quenching and tempering operation, Vickers hardness measurements were performed according to standard practice [13-14]. This was done on a Buhler 1105 machine. After that, samples 2 and 4 were plasma nitrided. The cleaning was performed in a mixture of hydrogen $(40 \mathrm{~L} / \mathrm{h})$, $\operatorname{argon}(5 \mathrm{~L} / \mathrm{h})$ and nitrogen $(1 \mathrm{~L} / \mathrm{h})$ inert gas. After that, the specimens were plasma nitrided at $480^{\circ}$ $\mathrm{C}$ for 24 hours in a mixture of hydrogen $(120 \mathrm{~L} / \mathrm{h})$ and nitrogen $(40 \mathrm{~L} / \mathrm{h})$ gas. After cooling, Vickers hardness measurements were performed. Samples 3 and 4 were subjected to a TiAlN PVD coating process, which was also followed by a Vickers hardness test. The final test for all four specimens was the abrasive wear test. Ball wear equipment was used for wear testing (Figure 2.). Before the wear test, the roughness was measured using the roughness measuring equipment shown in Figure 3. The abrasion ball was a $20 \mathrm{~mm}$ diameter $\mathrm{Al}_{2} \mathrm{O}_{3}$-based ceramic ball with a polished surface. The abrasion factor $(K)$ (1), which is calculated from the abrasion volume $\left(V_{v}\right)$, the abrasion path length $(S)$ and the load force $(N)$, was used as the wear indicator.

$$
K=\frac{V_{v}}{S N},\left(\frac{m^{3}}{N \cdot m}\right)
$$

The abrasion volume is calculated from the diameter of the abrasion trace $(d)$ and the depth of the spherical bottle $(h)(2)$ :

$$
V_{v}=\frac{h \pi}{6}\left(\frac{3}{4} d^{2}+h^{2}\right),\left(m m^{3}\right)
$$

The depth of the abrasive sphere is calculated by a simple relationship between the radius $R$ of the abrasion ball and the diameter of the abrasion imprint $(d=2 R)(3)$.

$$
h=R-\sqrt{R^{2}-\left(\frac{d}{2}\right)^{2}}, \quad(\mathrm{~mm})
$$

The wear path length $(S)$ depends on the wear time $(t)$, on the radius of the wear sphere and its speed $(n)(4)$ :

$$
S=n \cdot 2 \cdot \pi \cdot R \cdot t, \quad(m)
$$

To be comparable with the data in the literature, the speed was set at $570 \mathrm{rpm}$ and the abrasion test time was 5 minutes.

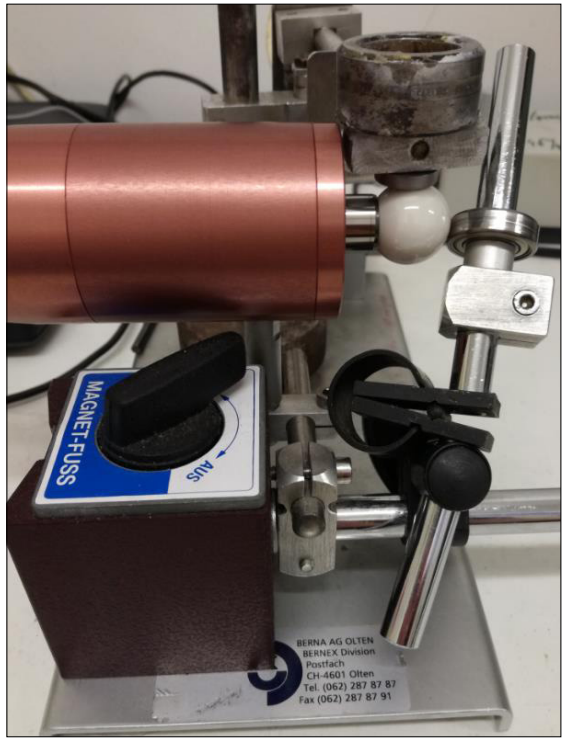

Figure 2. Ball wear equipment.

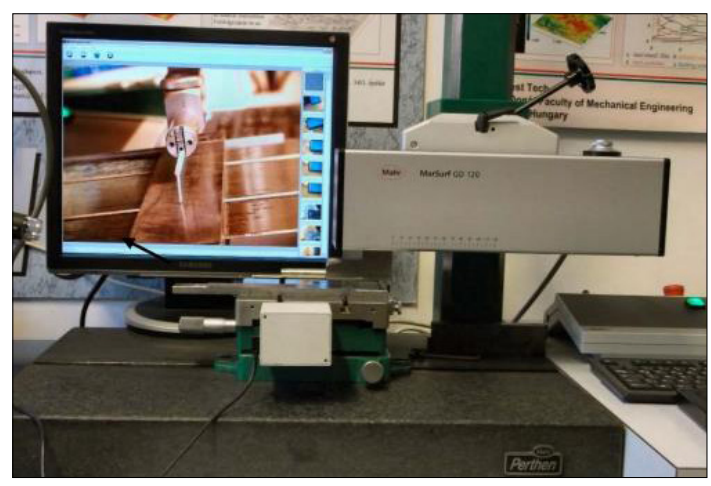

Figure 3. Mahr roughness tester.

\section{Test results}

In the delivery condition, the average hardness of the tool steel to be tested (X40CrMoV5-1) was 215 HV.

\subsection{Effects of the heat treatments (Table 2.)}

After quenching from $1050{ }^{\circ} \mathrm{C}$ and three times tempering at $520^{\circ} \mathrm{C}$ the hardness of the specimen was 549HV. After plasma nitriding, the hardness of the specimens 2 and 4 was 1140 HV. Sample 3, after the vacuum hardening was PVD coated with TiAlN coating and reached a surface hardness of 2938HV. Sample 4, after plasma nitriding, was PVD coated with TiAlN coating, so it was duplex surface treated and the result was a surface hardness of $2539 \mathrm{HV}$. 
Table 2. The hardness after heat treatments

\begin{tabular}{|c|l|c|c|}
\hline Sample & Heat treatment & $\begin{array}{c}\text { Coating } \\
\text { thickness } \\
(\boldsymbol{\mu m})\end{array}$ & $\begin{array}{c}\text { Hardness } \\
(\mathbf{H V})\end{array}$ \\
\hline 1 & $\begin{array}{l}\text { Quenched and } \\
\text { tempered }\end{array}$ & 0 & 549 \\
\hline 2 & $\begin{array}{l}\text { Quenched, tem- } \\
\text { pered and plasma } \\
\text { nitrided }\end{array}$ & 0 & 1140 \\
\hline 3 & $\begin{array}{l}\text { Quenched, tem- } \\
\text { pered and TiAlN } \\
\text { coated }\end{array}$ & 2.05 & 2938 \\
\hline 4 & $\begin{array}{l}\text { Quenched, tem- } \\
\text { pered, plasma } \\
\text { nitrided and } \\
\text { TiAlN coated }\end{array}$ & 1.93 & 2539 \\
\hline
\end{tabular}

\subsection{Effects of the heat treatments}

The abrasion factor calculated from roughness measurements and formula (1) is shown in the Table 3.

After the wear abrasion test, the diameters of the worn craters were measured with an optical microscope type Neophot 2. (Figure 4.).

\section{Conclusions}

The abrasion resistance results of the examined samples from material quality X40CrMoV5-1, treated with various heat treatments and surface treatments, are shown in Figure 5.

Based on the results, conclusions are as follows:

I. The TiAlN-based PVD coating showed the highest abrasion resistance based on experimental methods and parameters.

II. The hardness and wear factor of the test specimen with a plasma nitrided or PVD coated surface also resulted in much more favourable properties than the surface with only a hardened and tempered conventional heat treatment.

III. Plasma nitrided and PVD coated surfaces, however, have a lower hardness than hardened-welded and PVD coated surfaces resulting in better abrasion resistance. However, for this result to be accurately evaluated, it is important that the surface roughness of both specimens be identical.

\section{Acknowledgements}

This work was supported by the European Union and Hungarian State, National Research, Development and Innovation Office under the 2019-2.1.11-TÉT2019-00093 number project.
Table 3. Roughness and wear factor values

\begin{tabular}{|c|l|c|c|}
\hline $\begin{array}{c}\text { Sam- } \\
\text { ple }\end{array}$ & Heat treatment & $\begin{array}{c}\text { Ra } \\
(\boldsymbol{\mu m})\end{array}$ & $\begin{array}{c}\text { Wear factor } \\
\left(\mathbf{m m}^{3} / \mathbf{( N \cdot m ) )}\right.\end{array}$ \\
\hline 1 & $\begin{array}{l}\text { Quenched and } \\
\text { tempered }\end{array}$ & 0.010 & $6.32 \times 10^{-9}$ \\
\hline 2 & $\begin{array}{l}\text { Quenched, tem- } \\
\text { pered and plas- } \\
\text { ma nitrided }\end{array}$ & 0.057 & $1.95 \times 10^{-9}$ \\
\hline 3 & $\begin{array}{l}\text { Quenched, tem- } \\
\text { pered and TiAlN } \\
\text { coated }\end{array}$ & 0.233 & $8.46 \times 10^{-10}$ \\
\hline 4 & $\begin{array}{l}\text { Quenched, tem- } \\
\text { pered. plasma } \\
\text { nitrided and } \\
\text { TiAlN coated }\end{array}$ & 0.177 & $7.57 \times 10^{-10}$ \\
\hline
\end{tabular}

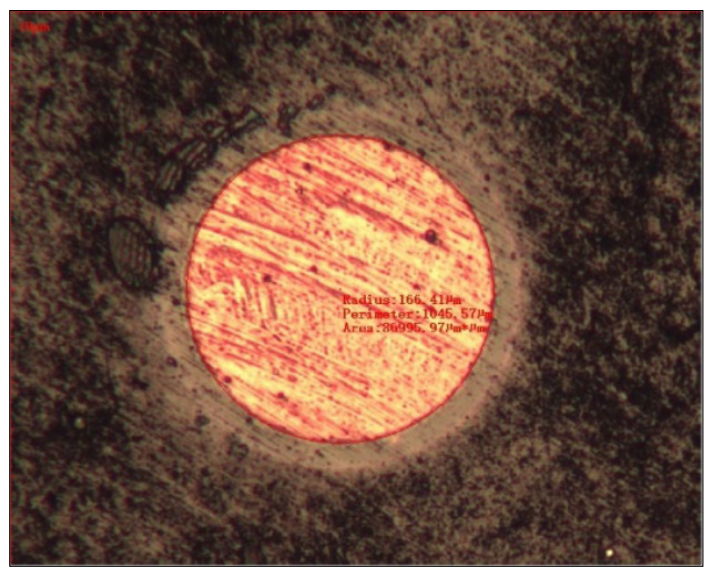

Figure 4. Wear imprint of sample nr. 3.

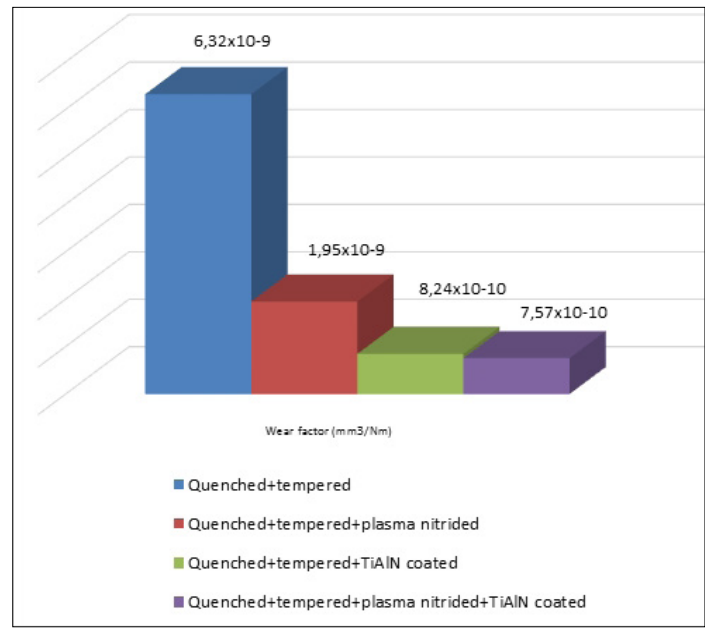

Figure 5. Measurement results: Effect of heat treatment and surface treatment technologies on the abrasion resistance of steel. 


\section{References}

[1] Takács L.: Szerszámacél ismertető - RIGOR hidegmunkaacél. Uddeholm

https://adoc.tips/szerszamacel-ismerteto-rigor-hidegmunkaacel-wherever-tools-a.html

[2] Borbély G.: Szerszámacélok, nemesacélok. Böhler Kereskedelmi Kft., 2009.

[3] Bitay E.: Bevonatolt gyorsacélok kopásállósága/ Coated HS steels wear resistance. In: XVIII. FMTÜ, EME, Kolozsvár, 2013. 73-76.

https://doi.org/10.36243/fmtu-2013.10

[4] Bagyinszki Gy., Bitay E.: Felületkezelés. Műszaki Tudományos Füzetek 5., EME, Kolozsvár, 2009. https://doi.org/10.36242/mtf-05

[5] Bagyinszky Gy., Bitay E.: Kopásálló felületkezelt rétegek minösítése/Characterization of surface treated, wear resistant layers. In: XIV. FMTÜ, Kolozsvár, 2009. 13-16.

https://doi.org/10.36243/fmtu-2009.08

[6] Tóth L.: Examination of the Properties and Structure of Tool Steel EN 1.2379 Due to Different Heat Treatments. European Journal of Materials Science and Engineering, 3/3. (2018) 165-170.

http://ejmse.tuiasi.ro/articles/EJMSE_03_03_06_ Toth.pdf

[7] Sebestyén A., Nagyné Halász E., Bagyinszky Gy., Bitay E.: Felületmódosítási eljárások hatása acélok kopásállóságára. In: XII. FMTÜ, EME, Kolozsvár, 2007. 161-169. https://doi.org/10.36243/fmtu-2007.4

[8] Tóth L., Haraszti F., Kovács T.: Surface Rougness Effect in the Case of Welded Stainless Steel Corrosion Resistance. In: Acta Materialia Transylvanica, 1/1. (2018) 53-56.

https://doi.org/10.2478/amt-2018-0018
[9] Titu M. A., Pop A. B., Titu S., Pop G. I.: Optimization of the objective function surface quality by end-milling dimensional machining of some aluminium alloys. ICIR Euroinvent, IOP Conf. Series: Materials Science and Engineering 572. (2019) https://doi.org/10.1088/1757-899x/572/1/012042

[10] Stescu C., Chicet D., Munteanu C., Croitoru C., Cârlescu V.: Machining of thermal sprayed coatings a case study for self fluxing powder. ICIR Euroinvent, IOP Conf. Series: Materials Science and Engineering 572. (2019), https://doi.org/10.1088/1757-899x/572/1/012051

[11] Sandu A. V., Baltatu M. S., Nabialek M., Savin A., Vizureanu P.: Characterization and Mechanical Properties of New TiMo Alloys for Medical Applications. Materials, 12/18. (2019), Art. nr. 2973. https://doi.org/10.3390/ma12182973

[12] Kovács T., Bitay E.: The hardness control in the coated surface layer. Materials Science Forum, 729. (2012) 415-418.

https://doi.org/10.4028/www.scientific.net/ MSF.729.415.

[13] Bitay E.: Lézeresen kezelt felületek kopásállósága. In: VI. FMTÜ, EME, Kolozsvár, 2001. 111-118. https://doi.org/10.36243/fmtu-2001.23

[14] Kovács-Coskun T., Pinke P.: The Effect on Microstructure on the Local Wear Behavior of Dual Phase Steels. IOP Conference Serie: Materials Science and Engineering, 47, (2013) 012032, https://doi.org/10.1088/1757-899X/47/1/012032. 